\title{
Tectonics-palaeogeomorphology in rift basins: controlling effect on the sequence architecture
}

\author{
Ji Hancheng ${ }^{1}$, Jia Haibo ${ }^{1 *}$, Sun Simin ${ }^{1}$, Chen Liang1, Tang Yang ${ }^{1}$, Chen Wei², \\ Geng Yikai ${ }^{1}$ and Zhou Hang ${ }^{1}$
}

${ }^{1}$ State Key Laboratory of Petroleum Resources and Prospecting, China University of Petroleum, Beijing 102249, China
${ }^{2}$ Geological Research Institute of Jiangsu Oilfield Branch Company, SINOPEC, Jiangsu 225009, China

(C) China University of Petroleum (Beijing) and Springer-Verlag Berlin Heidelberg 2013

\begin{abstract}
The relationship between deposition and tectonics of sedimentary basins has been a significant subject in recent years. Using typical rift basins such as the Nanpu Sag as an example, combined with the analysis of the tectonics-palaeogeomorphology of basins, we undertook a detailed study of the differences of the third-order sequences in different basins, the combination of depositional systems within the sequence framework and the distribution of depocenters and subsidence centers. Our results revealed a significant relationship between the tectonics-palaeogeomorphology of rift basins and the filling styles of sedimentary sequences. The basin structure plays a primary role in controlling the development of the third-order sequences and the boundary of these sequences is easily formed in basins with gentle slopes, shallow water and a small area. The characteristics of the tectonics-palaeogeomorphology of rift basins are dominated by half-grabens of extensional faults, which affect the temporal and spatial combination of sedimentary systems within the sequences as well as the distribution of depocenters and subsidence centers. Based on the development rules of the faults dominating the half-grabens of extensional faults, rift basins are classified into two types: the single fault segmented-linkage type and the multi-fault combination type. The main controlling factors of the temporal and spatial combination of sedimentary systems and the distribution of depocenters and subsidence centers in different basins are different. The characteristics of early segmentation and later linkage of the faults play a critical role in controlling the sedimentary system combination within the sequence framework and the temporal and spatial differences of depocenters and subsidence centers of the single fault segmented-linkage rift basins, while the differences in fault activities are the dominating factors of the multi-fault combination rift basins.
\end{abstract}

Key words: Tectonics-palaeogeomorphology, sequence architecture, extensional half-graben, Nanpu Sag

\section{Introduction}

Research into the relationship between tectonics and sedimentation in basins is a new direction in sedimentology, which is attracting increasing attention from geologists (Hentz et al, 2012; Armitage et al, 2012; Khani and Back, 2012; Leduc et al, 2012; Jin et al, 2013; Feng and Chao, 2012; Liu et al, 2012; Li et al, 2012; Wang and He, 2012; Lin et al, 2009). Inversion of the tectonic evolution history of basins by analyzing the characteristics of sedimentation and exploring the relationship between sedimentary sequence and tectonic changes of basins in different scales is definitely one significant frontier of current international basin analysis and sedimentology (Polyansky et al, 2013; Zecchin et al, 2012; Gugliotta and Morticelli, 2012; Schlüter and Uenzelmann-

*Corresponding author. email: jiahaibohb@163.com

Received June 20, 2013
Neben, 2007; Limarino et al, 2006). The unique tectonic setting of China results in numerous rift basins and widely distributed continental facies sequences (Huang et al, 2013; Yu et al, 2007), which is advantageous to some extent for the study of the tectonics and sedimentary sequence of rift basins. Consequently, comparing the differences of the basin characteristics and sequence filling structure, and building tectonics and sequence development sedimentary models of different basins to effectively enhance the prediction ability is of great significance to the development of theoretical sedimentology as well as petroleum exploration.

A series of basins with different tectonic characteristics and evolution is distributed in East China, whose development and evolution of depositional sequences also have significant differences (Wang et al, 2010). Using basins such as the Nanpu Sag of the Bohai Bay Basin and the Dongying Sag as examples, we studied in detail the development characteristics of faults and half-grabens, third-order sequences, the temporal 
and spatial combination of depositional systems and the changes of depocenters and subsidence centers. Our results reveal that tectonics-palaeogeomorphology plays a significant role in controlling the sequence architecture in rift basins.

\section{Temporal and spatial differences of sequence architecture in rift basins}

\subsection{Development characteristics of third-order sequence}

The Shahejie Formation (Es) and Dongying Formation (Ed) developed from bottom to top of the Paleogene in the Nanpu Sag, within which twelve third-order sequences existed including four in the third member of Es $\left(\mathrm{Es}_{3}\right)$, one in $\mathrm{Es}_{2}$, three in $\mathrm{Es}_{1}$, and four in Ed. While eight third-order sequences existed in the Paleogene in the Dongying Sag and numerous basins of the Bohai Sea, including three in $\mathrm{Es}_{3}$, one in $\mathrm{Es}_{2}$, one in $\mathrm{Es}_{1}$ and three in $\mathrm{Ed}$ (Fig. 1).

\subsection{Temporal and spatial distribution of sequences}

As regards the depositional sequence of rift basins, the planar distribution is of temporal and spatial imbalance, which can be evidenced by, for one thing, the existence of numerous depocenters and subsidence centers of different degrees, while for another thing, different temporal and spatial distributions and evolution of depocenters and subsidence centers in different basins. For the Dongying Sag and Nanpu Sag, the temporal and spatial distributions of depocenters and subsidence centers have both similarities and significant differences. The depocenters and subsidence centers of the two basins both show obvious migration. However, in terms of the continuity, the Dongying Sag is better than the Nanpu Sag. Moreover, the distribution orientation of the long axis of the depocenters and subsidence centers of different degrees in the Dongying Sag is consistently parallel to the main boundary fracture strike (Fig. 2(a), Fig. 2(b)). The situation for the Nanpu Sag is more complicated. During the sedimentation of Es, the depocenters and subsidence centers were distributed in the northern basin particularly the downthrown block of the Xinanzhuang and Bogezhuang Faults with significant segmentation, still following the rule of parallel with the main boundary fracture strike. While during the sedimentary period of the Dongying Formation, the depocenters and subsidence centers whose long axes are perpendicular to the strike of the Bogezhuang Fault migrated southwards with better continuity (Fig. 2(c), Fig. 2(d)).

\subsection{Depositional system combination within the sequence framework}

Based on the analysis of volcanic activity, regional stress field and subsidence history, the Paleogene of the Nanpu Sag is divided into four rifting episodes (Wang et al, 2010). Different rifting episodes correspond to different evolutionary stages of the basin, which caused different characteristics of sedimentary filling.

The Nanpu Sag experienced four evolutionary stages: (1) $\mathrm{Es}_{3}{ }^{4+5}$ sedimentary period (rifting episode I), (2) $\mathrm{Es}_{3}{ }^{3}-\mathrm{Es}_{2}$ sedimentary period (rifting episode II), (3) Es s $_{1}$ sedimentary

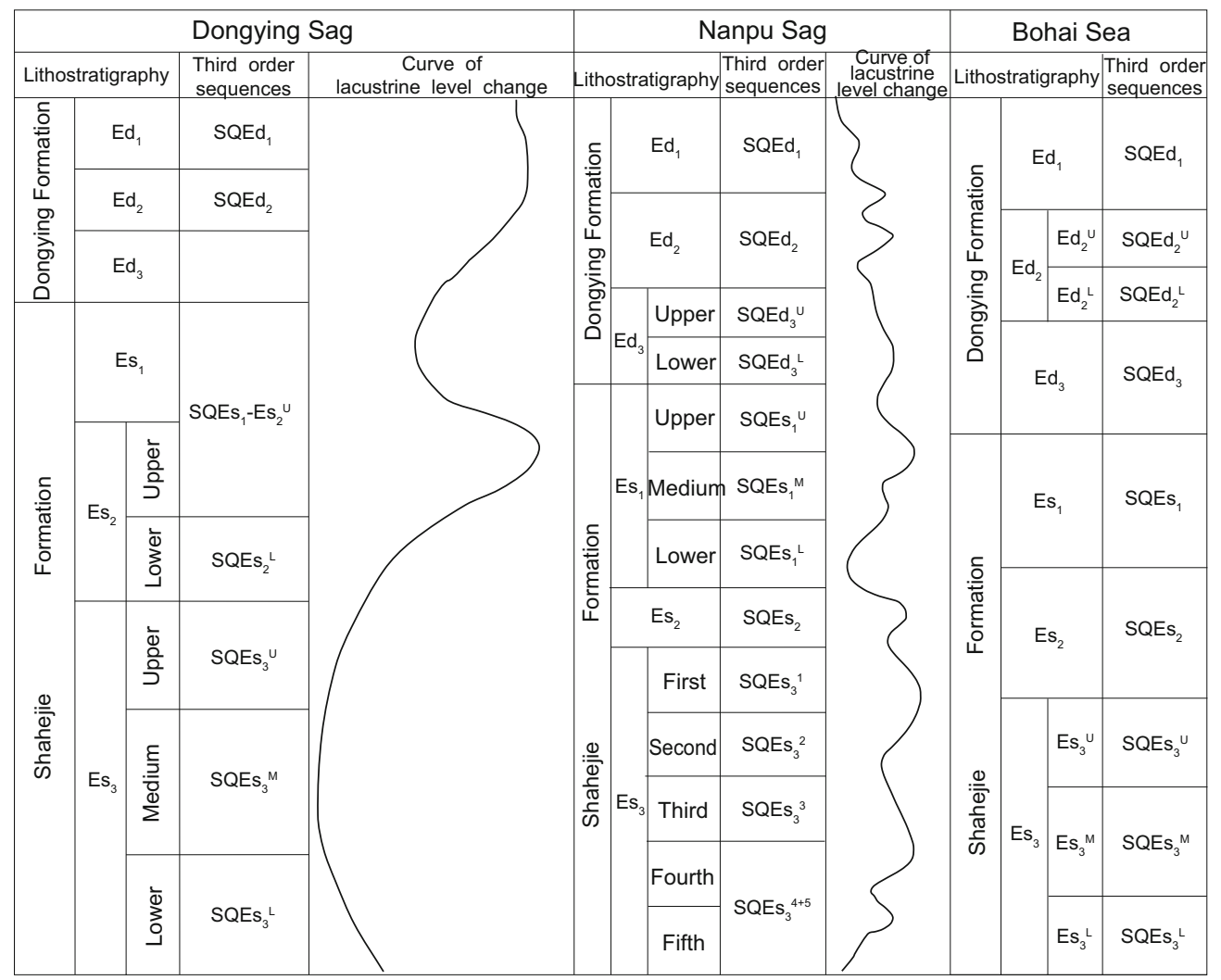

Fig. 1 Sequence stratigraphic framework of the Paleogene in the Nanpu Sag, Dongying Sag and Bohai Sea (Zhu et al, 2009) 


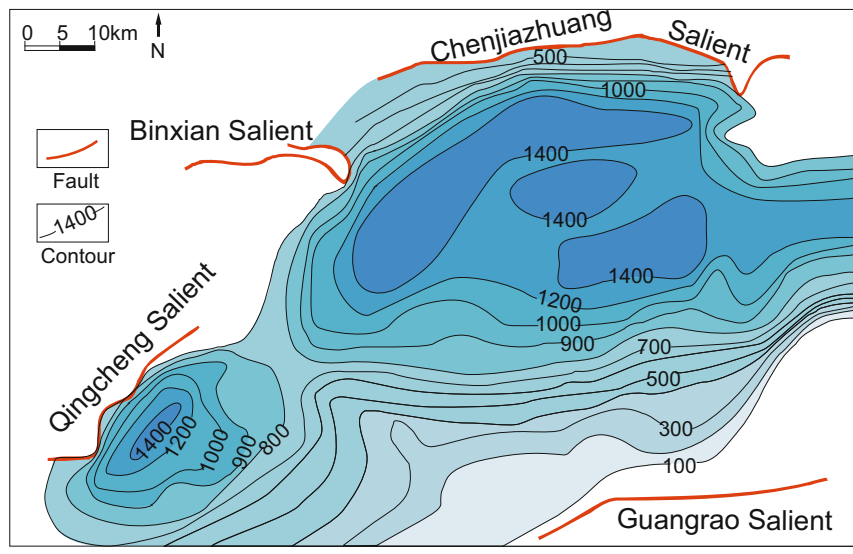

(a) $\mathrm{Es}_{3}-\mathrm{Es}_{2}{ }^{\mathrm{L}}$

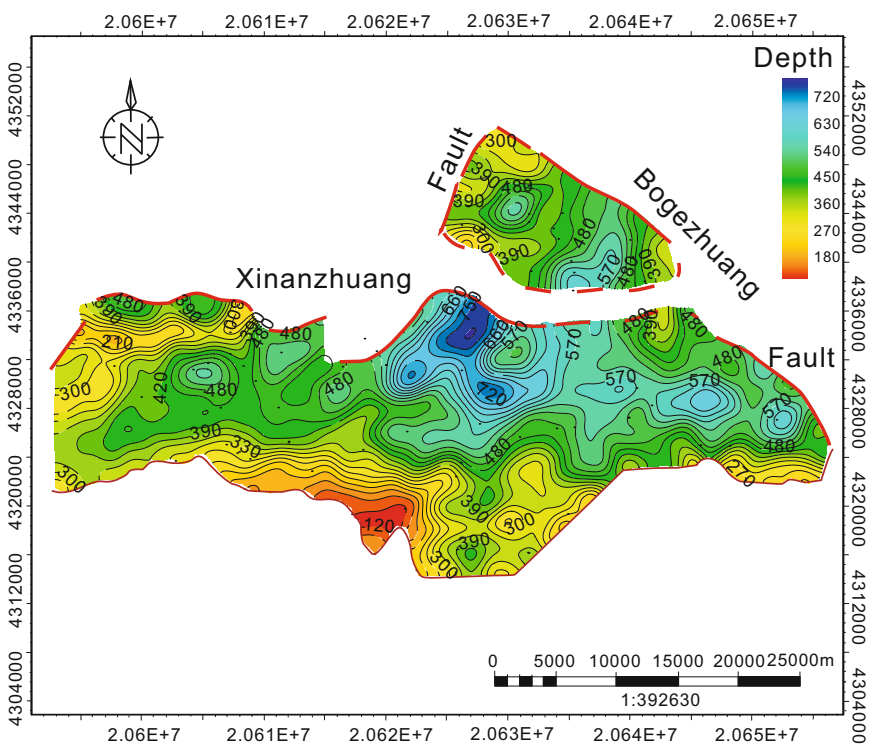

(c) $\mathrm{Es}_{3}{ }^{4+5}$

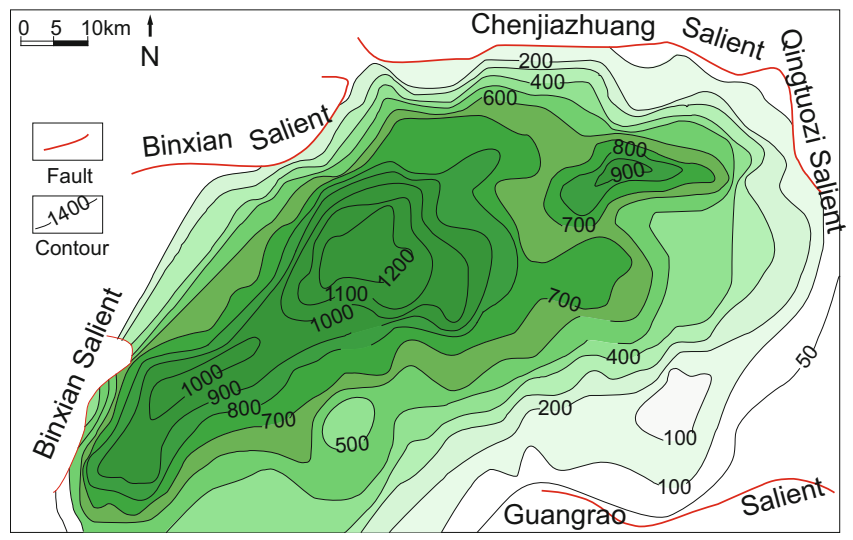

(b) $\mathrm{Es}_{2}{ }^{\mathrm{U}}-\mathrm{Ed}$

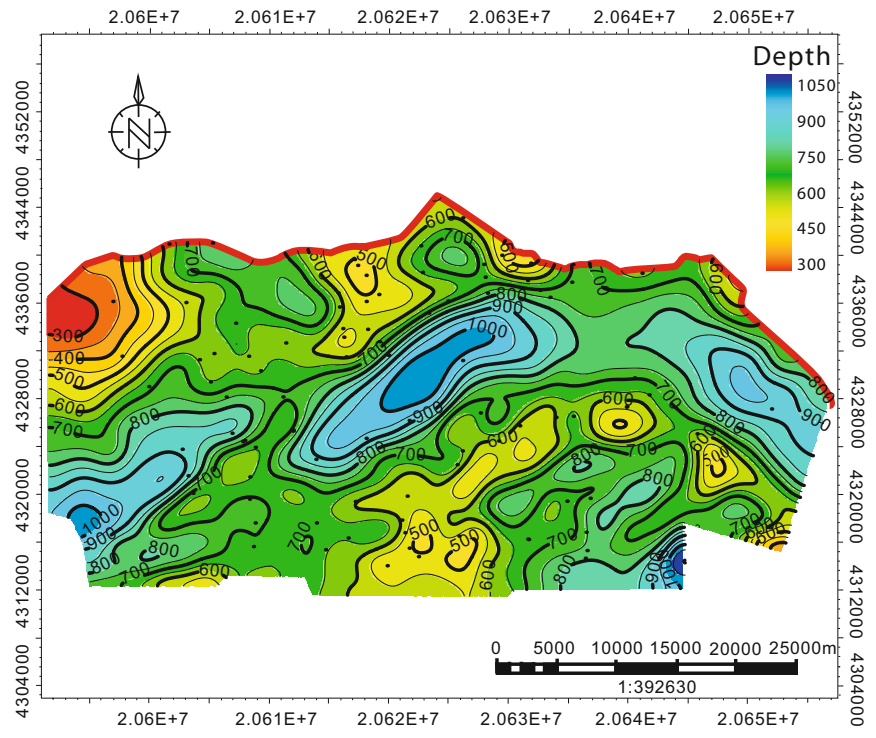

(d) $\mathrm{Ed}_{1}$

Fig. 2 Distribution of the remnant thickness of different sequences in the Dongying Sag and the Nanpu Sag

period (rifting episode III) and (4) Ed sedimentary period (rifting episode IV). These correspond with the filling sequences of (1) alluvial fan - fan delta - lake - braided delta system $\rightarrow$ (2) fan delta - lake - braided delta system $\rightarrow$ (3) alluvial fan - fan delta - lake - braided delta system $\rightarrow$ (4) fan delta and nearshore subaqueous fan - lake - braided delta system. Thus in the Nanpu Sag, the $\mathrm{Es}_{3}$ sedimentary period is mainly of arid type sequences in the initial rifting stage. Then deep-water sequences mainly developed in the deep-faulted period till the Ed sedimentary period.

In the $\mathrm{Es}_{3}$ sedimentary period, sedimentary assemblages of deep lake mudstone and oil shale, near-shore subaqueous fans and river deltas as well as sublacustrine fans mainly developed in the Dongying Sag and Chezhen Sag, which represented deep-water deposits in the strongly deepfaulted period. Fan delta, river delta and shallow lake facies dominated in the Ed sedimentary period which belonged to shallow water deposits of the shrinkage stage of the basins.

\section{Controlling factors of development differences of sequence architecture}

\subsection{Controlling effect of basin structure on the third- order sequence}

A sequence boundary is a response to a decline of baselevel. For rift basins, tectonics, sediment supply, climate and lake-level changes are the main controlling factors of the sedimentary base-level and of these tectonics and climate are the most basic factors (You and Liu, 2012; You et al, 2008; Chu et al, 2000; 2009).

$$
\Delta V_{\text {water }} \approx S \times \Delta h_{\text {water }}
$$

In the above equation, $\Delta V_{\text {water }}$ is the volume variation of water; $S$ is the area of lake-level (dominated by the area of basin); $\Delta h_{\text {water }}$ is the altitude variation of lake-level. 
In Fig. 3, A, B and C separately represent three basins of different structures. Different basin areas and slopes lead to significant differences in the variation of lake-level $\left(\Delta h_{\text {water }}\right)$ and the recession distance of lake-level $(\Delta l)$ resulting from tectonics and changes of climate. The lacustrine basin A has a large area and steep slope while the lacustrine basin B is small and gentle. With the same volume variation of water $\left(\Delta V_{\text {water }}\right)$, the altitude variation of lake-level of lacustrine basin $\mathrm{B}\left(\Delta h_{\mathrm{B}}\right)$ and the recession distance of lake-level $\left(\Delta l_{\mathrm{B}}\right)$ are much more than those of lacustrine basin A. Compared with lacustrine basin $\mathrm{C}$, which has a small area and gentle slope, lacustrine basin $\mathrm{A}$ is larger and steeper. With the same altitude variation of lake-level $\left(\Delta h_{\text {water }}\right)$, the recession distance of lakelevel of lacustrine basin $\mathrm{C}\left(\Delta l_{\mathrm{c}}\right)$ is larger.

In one place with the same climate, the effects of the climate changes on lake-level are dominated by the basin structure. Then there are two extreme situations. One is that for a small shallow-water basin with only a small volume of water, the changes of climate can lead to a large recession distance of shoreline towards the basin, which results in significant changes of the area of lake-level and a large erosional zone, being easier to form high-frequency sequence boundaries. The other is that for a large deep-water basin with huge volume of water, the recession distance of shoreline resulting from the same changes of climate is limited, which results in few changes of the area of lake-level and little erosional zone, consequently forming low-frequency sequence boundaries only.
During the $\mathrm{Es}_{3}$ sedimentary period in the Nanpu Sag, the basin was a small shallow-water lacustrine basin with water depth of 10-50 m (Yuan et al, 1994) and small water volume. The margins of the basin were gentle slopes. Highfrequency changes of climate led to changes of lake-level, which consequently made large recession distance, so that the erosional zone was large enough to be formed with numerous sequence boundaries (Fig. 3). During the $\mathrm{Es}_{3}$ sedimentary period the lake-level experienced four declines, and sequences were all third-order sequences which can be evidenced by the fact that each time span, accordingly with those changes, was about $3 \mathrm{Ma}$.

During the $\mathrm{Es}_{3}$ sedimentary period, the Dongying Sag and Chezhen Sag were in the period with large scale subsidence and a humid climate (Li et al, 2003; Zhu et al, 2000; Yao et al, 2007). The boundary faults experienced strong activity and large throws. Basins were mostly deep-water basins with large areas and huge water volumes. Consequently, the effects of the changes of lake-level on the shoreline resulting from the same climate condition were small. Only a short migration distance of shoreline towards the basin was formed with a small erosional zone, so the third-order sequence boundaries failed to form and a small amount of sequences developed.

Similarly, during the $\mathrm{Es}_{1}$ and Ed sedimentary periods, both area and depth of the Nanpu Sag were smaller than those of the Dongying Sag with relatively gentle slopes and small throw of boundary faults. Consequently a large amount of third-order sequences developed (Table 1, Table 2).

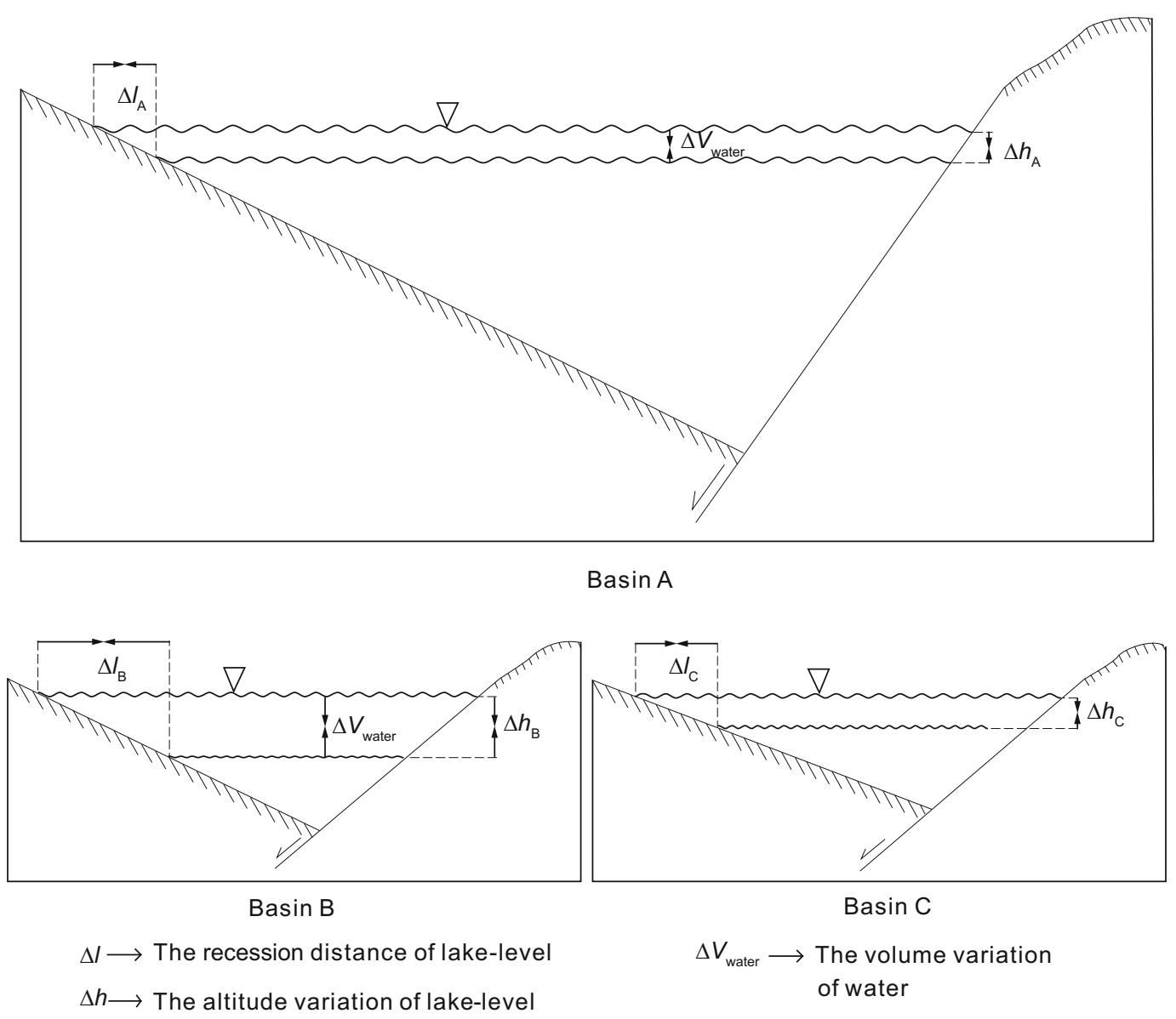

Fig. 3 Relationship of basin structure and the changes of lake-level 
Table 1 Areas and depths of lacustrine basins

\begin{tabular}{cccc}
\hline Sag & Area, $\mathrm{km}^{2}$ & $\begin{array}{c}\text { Average maximum } \\
\text { depth, } \mathrm{m}\end{array}$ & $\begin{array}{c}\text { Average minimum } \\
\text { depth, } \mathrm{m}\end{array}$ \\
\hline Dongying Sag & 6000 & 200 & 100 \\
Nanpu Sag & 1900 & 50 & 10 \\
\hline
\end{tabular}

\subsection{Controlling effects of half-grabens of extensional faults on the combination of depositional systems and sequence distribution}

A half-graben is the basic unit of rift basins (Ruke, 1990; Qi et al, 1997). It is commonly dominated by a boundary fault which is active in the central position while inactive at the

Table 2 Average activity velocities of main faults in different basins

\begin{tabular}{|c|c|c|c|c|c|c|}
\hline \multicolumn{4}{|c|}{ Dongying Sag } & \multicolumn{3}{|c|}{ Nanpu Sag } \\
\hline Geologic time & $\begin{array}{l}\text { West section } \\
\text { of the Chennan Fault, } \mathrm{m} / \mathrm{Ma}\end{array}$ & $\begin{array}{l}\text { East section } \\
\text { of the Chennan Fault, } \mathrm{m} / \mathrm{Ma}\end{array}$ & $\begin{array}{c}\text { Binnan Fault } \\
\mathrm{m} / \mathrm{Ma}\end{array}$ & Geologic time & $\begin{array}{c}\text { Xinanzhuang Fault } \\
\mathrm{m} / \mathrm{Ma}\end{array}$ & $\begin{array}{c}\text { Bogezhuang Fault } \\
\mathrm{m} / \mathrm{Ma}\end{array}$ \\
\hline $\mathrm{Es}_{3}$ & 130 & 110 & 75 & $\mathrm{Es}_{3}$ & 94 & 121.1 \\
\hline $\begin{array}{c}\text { Sha } 1 \text { Member } \\
E_{1}\end{array}$ & 57 & 46 & 57 & $\mathrm{Es}_{1}$ & 95.7 & 75.89 \\
\hline Ed & 20 & 17 & 18 & $\mathrm{Ed}$ & 268 & 198.36 \\
\hline
\end{tabular}

two ends (Schlische, 1991). The differences of characteristics of geometry and kinematics of the boundary fault dominate the temporal and spatial evolution of the half-graben topography and then affect the type and distribution of the depositional systems in basins. Moreover, the development and distribution of half-grabens also affect the distribution of sequence stratigraphy, thus controlling the sequence architecture of rift basins.

For the rift basins controlled by extensional faults, the controlling effects of fault activity on half-grabens are mainly of two types. The first type is single fault segmented linkage rift basins such as the Nanpu Sag and Dongpu Sag (Sun et al, 2003). The boundary faults of such basins commonly have large extensional distances, and the evolution process is characterized by segmentationlinkage. In the early development stage of faults, along the strike, the fault commonly consisted of several relatively independent segmentations with different activities and controlling different half-grabens. Accommodation structures developed among segmentations. Activity differences among the segmentations led to different structure characteristics of half-grabens. The fault throws were commonly large in the half-grabens where there was a sudden change of terrain while the terrain changed gradually in the accommodation structure. In the late period, the faults gradually connected to create a single unified fault. As the activity of faults became consistent, the structural differences among half-grabens also decreased. The initial small scale half-grabens connected to a unified large scale half-graben (Fig. 4). The other type is a multi-fault combination rift basin such as the Dongying Sag and Zhanhua Sag with several boundary faults of small scale and a short extensional distance with different temporal and spatial evolution characteristics. These faults are always segmented. Each fault controls a half-graben whose structural characteristics change with the changes of fault activities. Various accommodation belts are the boundaries of the faults. The differences of half-graben structures are determined by the controlling faults, which also affect the topographic characteristics of accommodation belts among faults with a positive correlation. Such changes of differences during geological history also lead to topographic changes of the

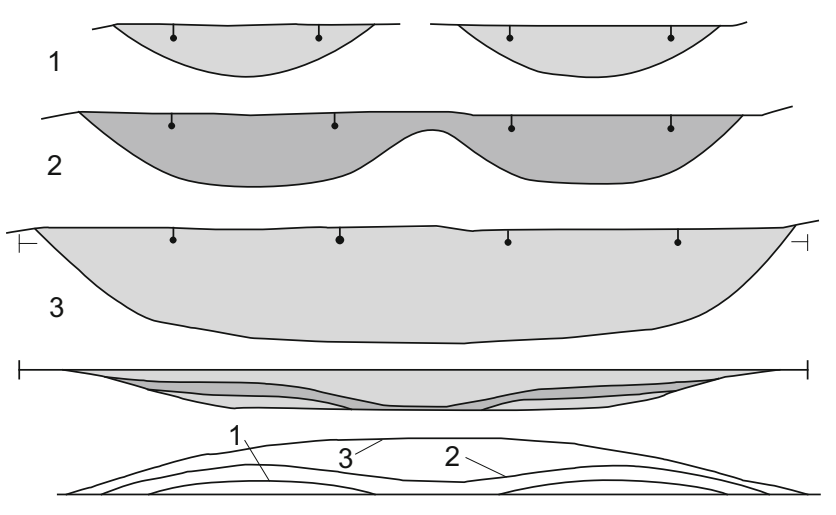

Fig. 4 Evolution model of the segmented-linkage and half-graben of extensional faults

accommodation belts.

\subsubsection{Effects on the temporal and spatial combination of depositional systems}

Based on the detailed interpretation of different seismic lines perpendicular to the Xinanzhuang and Bogezhuang Faults in the northern Nanpu Sag, combined with fault throw data, our results reveal that the two faults were both characterized by initial-segmentation and late-linkage which play a role in controlling the temporal and spatial combination of the depositional systems. Taking the Xinanzhuang Fault for an example, in the sedimentary period of Es, the differences of fault throw resulted in obvious multibranch faults along the strike. The branch faults had similar dip and slightly different strike with ends superimposed where the fault throw became significantly small with gentle slopes. The fault throw of branch faults was characterized by decreasing from the center to the ends, which formed and controlled half-grabens with different structures. Therefore diverse topographic characteristics (Fig. 5) were formed along the strike of the Xinanzhuang Fault, which dominated the type and distribution of sedimentary systems. In the half-grabens controlled by branch faults with large fault throws, steep slopes and deep water, deep-water mudstones commonly developed. With certain source conditions, nearshore subaqueous fans of near-source rapid accumulation 
also developed, which were mainly of vertical stack as well as limit extension of horizontal distribution. While in the superposition of branch faults with small fault throw, gentle slopes and shallow water, mainly fan deltas developed, which extended to a large scale horizontally but had relatively small vertical thickness (Fig. 5). The Ed sedimentary period is the rift reactivation episode of the Nanpu Sag. With strong activity of the faults, the differences of fault throw along strike decreased. While the branch faults began to connect and the Xinanzhuang Fault gradually showed characteristics of one fault system. The initial small scale half-grabens connected to a uniform large scale half-graben. During this period, near-shore subaqueous fans and large scale deepwater deposits developed due to the large fault throw, steep slopes and deep water. Fan deltas developed in other regions where the fault throw was small and the water was shallow.

The north boundary of the Dongying Sag in the Jiyang Depression is mainly controlled by the Chennan Fault and Binnan Fault (Yan et al, 2005). The half-graben structure is dominated by the temporal and spatial differences of the boundary fault activities, which affected the temporal and spatial distribution of the depositional systems of the Dongying Sag (Ye et al, 2006). The $\mathrm{Es}_{3}$ sedimentary period was the peak rifting period of the Dongying Sag (Ma et al, 2000), during which the active velocity of the $\mathrm{Es}_{3}$ sedimentary period of the Chennan Fault reached $130 \mathrm{~m} / \mathrm{Ma}$ and the active velocity of the Binnan Fault also could be up to $75 \mathrm{~m} / \mathrm{Ma}$. The faults were of large throw, steep sections (Kong, 2000) and deep water, which were typical deep basin - deep water halfgrabens with mainly near-shore subaqueous fans developing. While in the superposition regions of the Chennan Fault and Binnan Fault which were at the ends of extensional faults, the fault throw was small with gentle sections and slopes (Sun and Ren, 2004). Consequently mainly progressive fan deltas developed (Yan et al, 2005). During the Ed sedimentary period, the Dongying Sag tended to shrink with the boundary fault activity being significantly weakened. The active velocity of the Chennan Fault was about $20 \mathrm{~m} / \mathrm{Ma}$ while that of the Binnan Fault was about $17 \mathrm{~m} / \mathrm{Ma}$. The basin was mainly of shallow shore and half-deep lacustrine environment with faults of small throw, gentle slopes, and fan deltas and deltas developed.

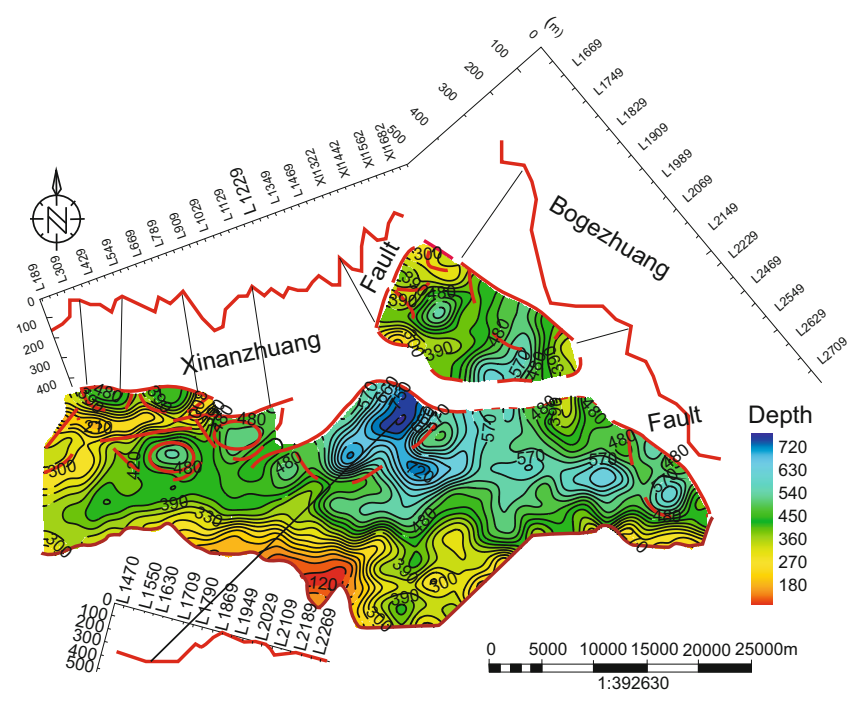

(a) $\mathrm{Es}_{3}{ }^{4+5}$

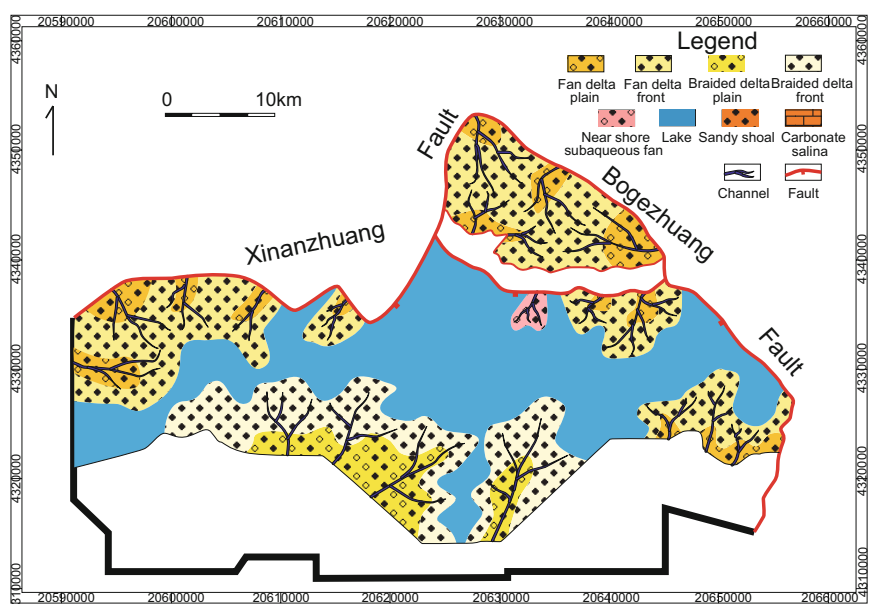

(c) $\mathrm{Es}_{3}{ }^{4+5}$

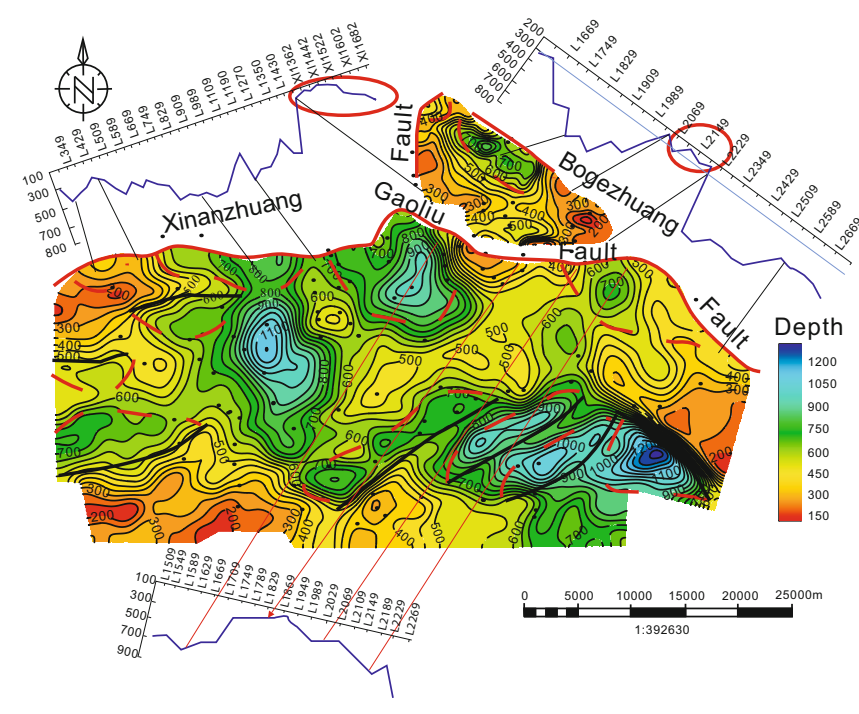

(b) $\mathrm{Ed}_{3}^{\mathrm{L}}$

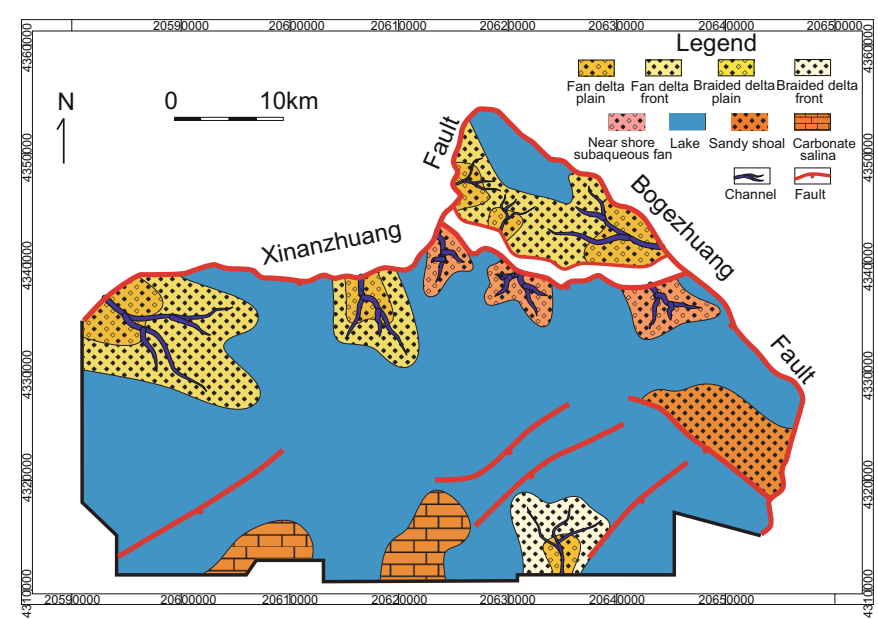

(d) $\mathrm{Ed}_{3}^{\mathrm{L}}$

Fig. 5 The development characteristics of fault throw and half-grabens and the combination of depositional systems in different periods of the Nanpu Sag 


\subsubsection{Temporal and spatial distribution of the half-grabens of extensional faults and depocenters and subsidence centers}

On the basis of the analysis of the distribution of sequences in the Nanpu Sag and Dongying Sag, combined with the study of the fault throw, we concluded that the temporal and spatial distribution of depocenters and subsidence centers in each period was dominated by the temporal and spatial differences of the boundary fault activities as well as the development characteristics of the controlled half-grabens.

The segmentation-linkage of boundary faults and the development of the NE second-grade faults are the main controlling factors on the distribution of depocenters and subsidence centers in the Nanpu Sag. In the $\mathrm{Es}_{3}{ }^{4+5}$ sedimentary period, the Xinanzhuang Fault with the segmental property of the strike dominated the half-grabens with different structures. The fault throw there was large and decreased to the ends (Fig. 2(c)-2(d)). While among the

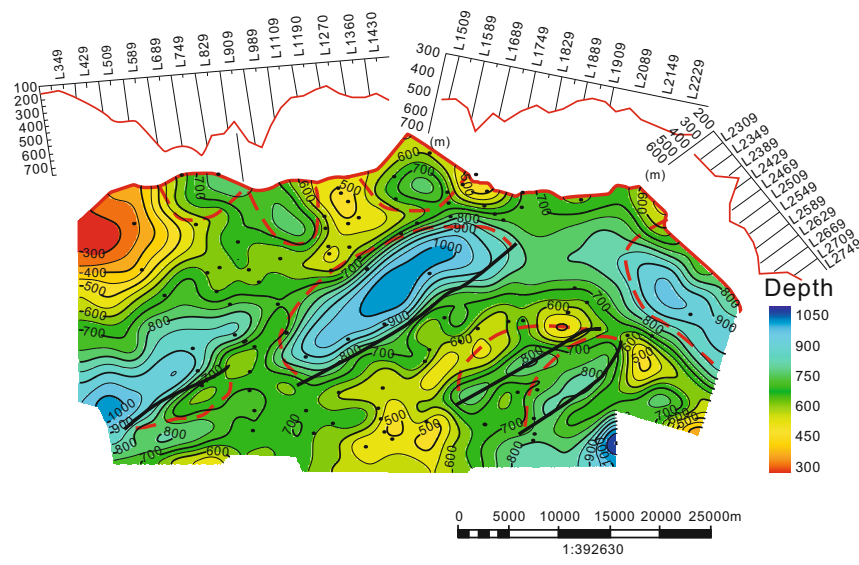

Fig. 6 The development characteristics of fault throw and half-grabens and the distribution of depocenters and subsidence centers of Ed ${ }_{1}$ in the Nanpu Sag

For the Dongying Sag, the activity differences of boundary faults play a significant role in controlling the different temporal and spatial developments of the depocenters and subsidence centers in the basin. During the sedimentary period of $\mathrm{Es}_{3}-\mathrm{Es}_{2}{ }_{2}^{\mathrm{L}}$, the faults with large throws included the Chennan, Binnan and Gaoqing-Pingnan Faults, forming a nearly $\mathrm{NE}$ trending arc fracture zone that controlled the large half-grabens of the NW fault and the SE overlap. Meanwhile the thickness of sequences was also controlled by the half-graben structure. The thickness center was located near the downthrow side of the fault with large scale and good continuity. During $\mathrm{Es}_{2}{ }^{\mathrm{U}}-\mathrm{Ed}$ sedimentary period, the main active faults were still the Chennan, Binnan and GaoqingPingnan Faults. As the fault throw of the Chennan Fault and Gaoqing-Pingnan Fault was relatively small, the Binnan halfgraben was the largest. Therefore, the thickness center of $\mathrm{Es}_{2}{ }^{\mathrm{U}}$-Ed was divided into three sections among which the thickest one was located in the Binnan half-graben (Fig. 2(a)2(b)). half-grabens, the fault throw was small and the geography was high. According to the contour of residual formations in $\mathrm{Es}_{3}{ }^{4+5}$, the depocenters and subsidence centers were mainly distributed on the downthrow side of the Xinanzhuang Fault, and were mostly distributed in extensional half-grabens with large fault throw and thin strata among them (Fig. 2(c)-2(d)). During the $\mathrm{Ed}_{1}$ sedimentary period, the fault throw differences along the strike of the Xinanzhuang Fault gradually decreased and it started to act as a complete fault system. The whole sag became a uniform large scale half-graben. Moreover, the extensional half-graben controlled by the NE-trending secondary faults appeared with the strike perpendicular to the Bogezhuang Fault, which was shown in the thickness figure of $\operatorname{Ed}_{1}$ (Fig. 6). The sequence distribution area significantly extended and the thickness centers were continuous as well as uniform. Liunan and Linque are two thickness centers parallel with the north boundary faults, and in the sub-half-grabens the Nanpu $1^{\#}$ tectonic zone and Nanpu $4^{\#}$ tectonic zone were thickness centers.

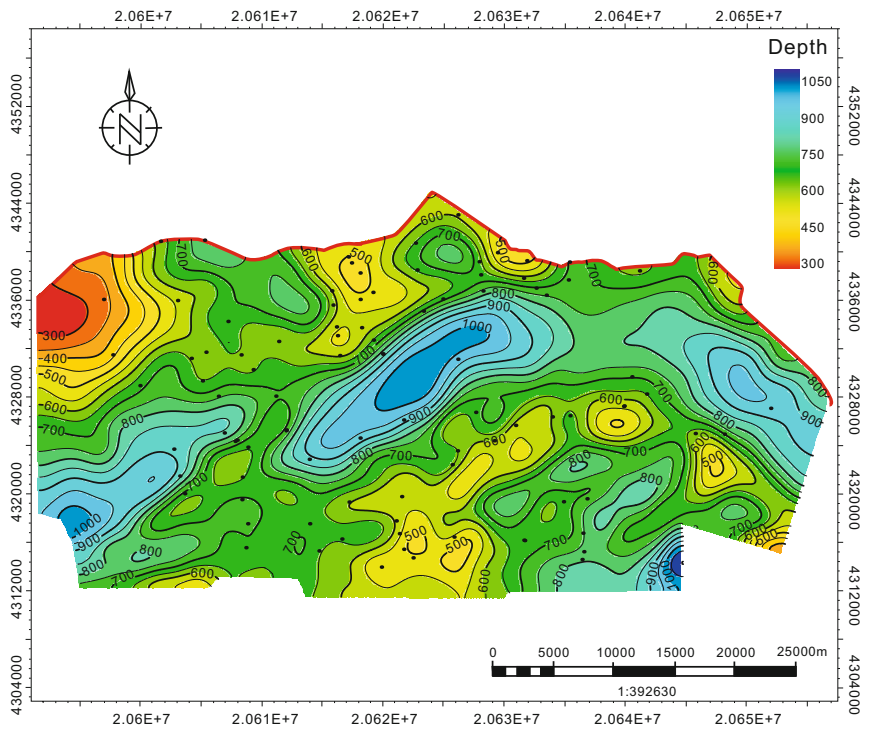

\section{Conclusions}

1) Sequence architectures vary in different basins. Tectonic-palaeogeomorphological characteristics play a significant role in controlling the third-order sequence development characteristics. The temporal and spatial combination of sedimentary systems within the sequence framework and the distribution of depocenters and subsidence centers of rift basins show different sequence architectures.

2) The development of the third-order sequences is dominated by the differences of the basin structures. The temporal and spatial combination of sedimentary systems within the sedimentary sequences and the migration of depocenters and subsidence centers are dominated by the fault-controlling extensional half-grabens and their combination characteristics.

\section{References}

Armitage D A, McHargue T, Fildani A, et al. Pre-avulsion levee and post 
avulsion channel evolution: Niger Delta continental slope. AAPG Bulletin. 2012. 96(5): 823-843

Chu G Q, Liu J Q and Liu D S. Discrimination of two kinds of sedimentary laminae in maar lakes of China. Chinese Science Bulletin. 2000. 45(24): 2292-2295

Chu G Q, Sun Q, Wang X H, et al. A 1600 year multiproxy record of paleoclimatic change from varved sediments in Lake Xiaolongwan, northeastern China. Journal of Geophysical Research: Atmospheres. 2009. 114(D22): 108

Feng L C and Chao J P. Continental shelf waves forced by nonlinear continental shelf topography. Science in China Earth Sciences. 2012. 55(10): 1702-1705

Gugliotta C and Morticelli M G. Using high-resolution stratigraphy and structural analysis to constrain polyphase tectonics in wedge-top basins: Inferences from the late Tortonian Scillato Basin (centralnorthern Sicily). Sedimentary Geology. 2012. 273-274: 30-47

Hentz T F, Ambrose W A and Carr D L. Reservoir systems of the Pennsylvanian lower Atoka Group (Bend Conglomerate), northern Fort Worth Basin, Texas: High-resolution facies distribution, structural controls on sedimentation, and production trends. AAPG Bulletin. 2012. 96(7): 1301-1332

Huang C Y, Yen Y, Liew P M, et al. Significance of indigenous Eocene larger foraminifera Discocyclina dispansa in Western Foothills, Central Taiwan: A Paleogene marine rift basin in Chinese continental margin. Journal of Asian Earth Sciences. 2013. 62: 425-437

Jin Z J, Yuan Y S, Liu Q Y, et al. Controls of Late Jurassic-Early Cretaceous tectonic event on source rocks and seals in marine sequences, South China. Science in China Earth Sciences. 2013. 56(2): 228-239

Khani H F and Back S. Temporal and lateral variation in the development of growth faults and growth strata in western Niger Delta, Nigeria. AAPG Bulletin. 2012. 96(4): 595-614

Kong F X. The exploration of glutenite in the northern steep slope of Dongying Sag. Oil Geophysical Prospecting. 2000. 35(5): 669-676 (in Chinese)

Leduc A M, Davies R J, Densmore A L, et al. The lateral strike-slip domain in gravitational detachment delta systems: A case study of the northwestern margin of the Niger Delta. AAPG Bulletin. 2012. 96(4): 709-728

Li L, Wang Y M, Xu Q, et al. Seismic geomorphology and main controls of deep-water gravity flow sedimentary process on the slope of the northern South China Sea. Science in China Earth Sciences. 2012. 55(5): 747-757

Li S J, Wang M Z, Zheng D S, et al. Recovery of climate of Palaeogene in Jiyang Depression of Shandong. Journal of Shandong University of Science and Technology. 2003. 22(3): 6-9 (in Chinese)

Limarino C, Tripaldi A, Marenssi S, et al. Tectonic, sea-level, and climatic controls on Late Paleozoic sedimentation in the western basins of Argentina. Journal of South American Earth Sciences. 2006. 22(3-4): 205-226

Lin C S, Yang H J, Liu J Y, et al. Paleostructural geomorphology of the Paleozoic central uplift belt and its constraint on the development of depositional facies in the Tarim Basin. Science in China Series D: Earth Sciences. 2009. 52(6): 823-834

Liu J Q, Li Z, Huang J C, et al. Distinct sedimentary environments and their influences on carbonate reservoir evolution of the Lianglitage Formation in the Tarim Basin, Northwest China. Science in China Earth Sciences. 2012. 55(10): 1641-1655

Ma L J, He X Z, Wang S L, et al. Subsidence history analysis and structural filling evaluation in Dongying Depression. Oil Geophysical Prospecting. 2000. 35(6): 786-794 (in Chinese)

Polyansky O P, Prokop'ev A V, Babichev A V, et al. The rift origin of the Vilyui Basin (East Siberia), from reconstructions of sedimentation and mechanical mathematical modeling. Russian Geology and Geophysics. 2013. 54(2): 121-137

Qi J F, Yang Q, Tong H M, et al. Sequence construction response to tectonic process in extensional half-graben basin. Earth Science (Journal of China University of Geosciences). 1997. 22(6): 603-608 (in Chinese)

Ruke. Analysis on the half-grabens of rift basins. China Offshore Oil and Gas (Geology). 1990. 4(6): 1-10 (in Chinese)

Schlische R W. Half-graben basin filling models: New constraints on continental extensional basin development. Basin Research. 1991. 3: 123-141

Schlüter P and Uenzelmann-Neben G. Seismostratigraphic analysis of the Transkei Basin: A history of deep sea current controlled sedimentation. Marine Geology. 2007. 240(1-4): 99-111

Sun S M, Peng S M and Wang X W. Segmentation characteristics of Lanliao Fault in Dongpu Depression. Acta Petrolei Sinica. 2003. 24(4): 26-30 (in Chinese)

Sun X Y and Ren J Y. Transfer zone and its relative reservoir distribution in northern zone of Dongying Sag. Petroleum Exploration and Development. 2004. 31(1): 21-23 (in Chinese)

Wang H, Liao Y T, Lu Y C, et al. Sequence architecture styles of Cenozoic continental rift basins in East China. Journal of Central South University (Science and Technology). 2010. 41(1): 277-285 (in Chinese)

Wang X F and He J K. Channel flow of the lower crust and its relation to large-scale tectonic geomorphology of the eastern Tibetan Plateau. Science in China Earth Sciences. 2012. 55(8): 1383-1390

Yan J H, Chen S Y and Jiang Z X. Sedimentary characteristics of nearshore subaqueous fans in steep slope of Dongying Depression. Journal of the University of Petroleum, China. 2005. 29(1): 12-16 (in Chinese)

Yao Y M, Xu D Y and Zhang H F. A brief introduction to the Cenozoic astrostratigraphic time scale for the Dongying Depression, Shandong. Journal of Stratigraphy. 2007. 31(supplement 2): 423-429 (in Chinese)

Ye X S, Wang W F, Chen S Y, et al. Characteristics of the fault activities in Dongying Depression and their controlling effects on sediment. Journal of Xi'an Shiyou University (Natural Science Edition). 2006. 21(5): 29-33 (in Chinese)

You H T and Liu J Q. High-resolution climate evolution derived from the sediment records of Erlongwan Maar Lake since $14 \mathrm{ka}$ BP. Chinese Science Bulletin. 2012. 57(27): 3610-3616

You H T, Liu J Q, Liu Q, et al. Study of the varve record from Erlongwan Maar Lake, NE China, over the last $13 \mathrm{ka}$ BP. China Science Bulletin. 2008. 53: 262-266

Yu X H, Jiang H, Li S L, et al. Depositional filling models and controlling factors on Mesozoic and Cenozoic fault basins of terrestrial facies in eastern China: A case study of Dongying Sag of Jiyang Depression. Lithologic Reservoirs. 2007. 19(1): 39-45 (in Chinese)

Yuan X J, Xue S H and Wang K Y. Sedimentary features and sequence stratigraphy of Eogene system in Nanpu Depression. Petroleum Exploration and Development. 1994. 21(4): 87-94 (in Chinese)

Zecchin M, Caffau M, Civile D, et al. The Plio-Pleistocene evolution of the Crotone Basin (southern Italy): Interplay between sedimentation, tectonics and eustasy in the frame of Calabrian Arc migration. Earth Science Reviews. 2012. 115(4): 273-303

Zhu W L, Mi L J and Gong Z S. Hydrocarbon Accumulation and Exploration in Bohai Bay. Beijing: Science Press Ltd. 2009 (in Chinese)

Zhu Z H, Fan N M and Luo H Y. Climate of Shengli Oil Field in Tertiary. Geology of Shandong. 2000. 16(1): 22-28 (in Chinese)

(Edited by Hao Jie) 